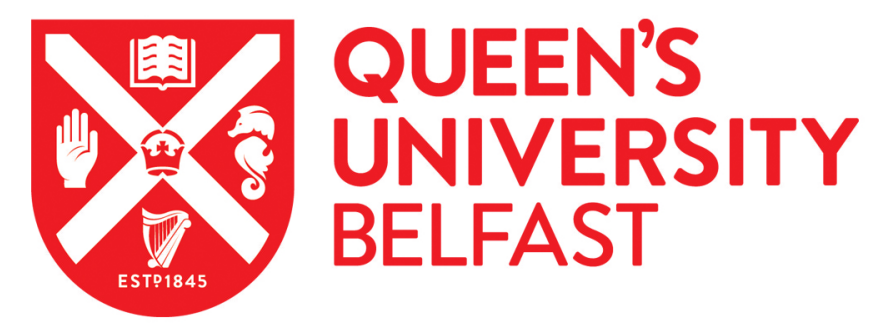

\title{
A Greener Gothic: Environment and Extinction in Elizabeth Bowen's The Demon Lover (1945)
}

Sturgeon, S. (2020). A Greener Gothic: Environment and Extinction in Elizabeth Bowen's The Demon Lover (1945). Éire-Ireland, 55(3\&4), 75-94.

\section{Published in:}

Éire-Ireland

\section{Document Version:}

Peer reviewed version

Queen's University Belfast - Research Portal:

Link to publication record in Queen's University Belfast Research Portal

Publisher rights

(C) 2020 The Irish American Cultural Institute.

This work is made available online in accordance with the publisher's policies. Please refer to any applicable terms of use of the publisher.

\section{General rights}

Copyright for the publications made accessible via the Queen's University Belfast Research Portal is retained by the author(s) and / or other copyright owners and it is a condition of accessing these publications that users recognise and abide by the legal requirements associated with these rights.

Take down policy

The Research Portal is Queen's institutional repository that provides access to Queen's research output. Every effort has been made to ensure that content in the Research Portal does not infringe any person's rights, or applicable UK laws. If you discover content in the Research Portal that you believe breaches copyright or violates any law, please contact openaccess@qub.ac.uk. 


\section{Sinéad Sturgeon A Greener Gothic:}

\section{Environment and Extinction in Elizabeth Bowen's}

\section{The Demon Lover (1945)}

"Elizabeth Bowen was a gardener," the English novelist Penelope Lively (herself a keen horticulturist) suspected, remarking on how the Irish writer "frequently gives fictional space to gardens, or flowers, and with intent" (54). Lively comments that Bowen "can flourish a garden to define the personality of its owner" (55) and references a striking description of dahlias in The Little Girls (1964): "some dwarf, some giant, some corollas like blazons, some close-fluted, some velvet, some porcelain or satin, some darkening, some burning like a flame or biting like acid into the faint dusk now being given off by the evening earth" (17). Certainly, as Lively concludes in Life in the Garden, Bowen "knew a thing or two about dahlias" (55).

Such concrete botanical knowledge is frequently visible in Bowen's numerous literary representations of flowers, as well as of trees, plants, and gardens - an aspect of her imagination that complicates her reputation as a writer chiefly fascinated by the great indoors. Gardening and images of the organic also functioned for Bowen as a means of conceptualizing creativity and its cultural productions. She describes the bestseller as "rather like a pretty annual, you've got a nice show of flowers and leaves, but when they wither, there's nothing left at all," whereas "[t]he other sort of book is more like a tree. It's quite true that while the leaves are out, it looks especially attractive, but even when they're gone there's a trunk, a solid shape left" (Listening In 264). She revised her manuscripts "like one prunes-snipping away dead wood" (269), and literary influences on a developing writer are "rather like a palisade round a young growing tree" (328). "For the work - the writing-itself," she preferred "an as nearly as possible quiet room. [. . .] I like best trees outside the window. As 
to this, in London I'm fortunate-I live overlooking a park. And in Ireland my old home, where I do much work, is deep in the heart of the country" (90). Bowen characterized herself as rural rather than urban by temperament, her ideal home being a "house in the country; enough but not too much garden" (232; my emphasis). That qualifier is intriguing: what might it mean to have too much garden? Bowen's curious phrase suggests an anxiety about the natural world and its abundant procreative potential that is implicitly threatening - a motif that will be central to the argument developed in the follow- ing pages. Psychologically as well as imaginatively, the natural world was of immense significance to Bowen's life and writing, unlocking heretofore unexplored dimensions of her fiction.

Critics have generally been preoccupied with Bowen's manmade architecture and domestic interiors. Studies of her short fiction espe- cially have oriented themselves around the house-and with good reason. ${ }^{1}$ Houses are central to Bowen's imagination and dominate three of the areas in which she is most often studied: the gothic, Irish Studies, and World War II. Houses lend themselves in obvious ways to gothic narrative; they gain a particular poignancy in writing about the big house that, as British colonial power waned in the early twentieth century, no longer dominated but rather haunted the Irish landscape. Houses also multiply in Bowen's war writing, figuring the sudden fragility of what had seemed invulnerable. ${ }^{2}$ Both contexts-Anglo- Ireland and World War IIforeground violence, transience, and loss, but also a kind of ghostliness: these were buildings haunted both by the past and by the imminence of their own destruction. Although the natural world has long been an impetus central to gothic imag- inings, it has received rather less exacting critical attention. ${ }^{3}$ I focus

1. For example, see Lassner (1991), D’hoker (2012), and Lytovka (2016). An important exception to this trend is Jeannie Im's work on Bowen's aesthetics of landscape representation (2015). Im's analysis focuses on the sociopolitical import of Bowen's landscapes, extending the interior out, whereas here I am interested in a more ontological engagement with the natural world.

2. "The violent destruction of solid things, the explosion of the illusion that prestige, power, and permanence attach to bulk and weight," Bowen writes in the postscript to The Demon Lover, "left all of us, equally, heady and disembodied" (191).

3. See Andrew Smith's and William Hughes's introduction to their collection Ecogothic (2013). Scholarship of Irish gothic writing is largely centered on questions of history and politics. 
here on The Demon Lover (1945), a group of short stories that Bowen wrote during World War II, and argue that foregrounding the significance of the natural world in shaping her depiction of wartime London reveals an underappreciated aspect of her literary imaginationespecially in its more gothic reaches. The intersection of domestic space and what might be described as a "gothicized nature"- a natural world imbued with supernatural agency and inimically disposed to its human occupiers - allows Bowen to critique gothic convention as well as to pose fundamental questions about the ontology of the nonhuman and humanity's complex relation to the otherness of the natural world. In her wartime stories nature serves neither as mere backdrop nor mute accessory; it is, rather, an active player in a sustained reflection on man's brute existence in the world when human extinction is a real possibility. At the onset of World War II nature itself-alongside history - becomes a force with which humanity must reckon; the otherness of the natural world's primeval power endows it with gothic shades of haunting, desuetude, and decay. This greener gothic is rooted in the writer's Irish background, a country she associated with natural abundance - even the threat of too much abundance. In an essay first published in 1946 Bowen elaborates on the domestic horticulture of her home country:

Gardening, in this country, rapidly becomes an infatuation-and, indeed, what gardens there are to show! The alluvial soil round the river houses, the steamy, moist, sheltered heat of the valleys, produces a luxuriance that is almost frightening. The conformation of the ground, so often, above rivers in natural terraces, tempts the gardener on and on into further landscape effects. Ruined towers are niched and draped with bloom. The walls and yew or beech hedges of the enclosed gardens make ideal backgrounds for deep herbaceous borders. From peaty soil, azaleas and rhododendrons blaze through the early summers. Tropic speed and richness of growth, here, of course, cut both ways - allow a few months to elapse and Nature, with her own inordinate beauty, has obliterated all marks of man's, or of woman's, hand. (People, Places, Things 158)

On the heels of the devastation of the Second World War, Bowen voices anxiety about a natural world that is "almost frightening" in its invasive, obliterating proliferation. Such a view of nature-with an interest in visual aesthetics alongside an awareness of uncanny 
agency and existential threat - constitutes a malign picturesque, one ripe with gothic potential. Reflecting its longstanding status as gothic site in the British imaginary, Ireland is at the heart of Bowen's uneasy engagement with the natural world. This Irish matrix proves crucial for her depiction of nature in 1940s London, a city "organically dislocated" by the shock and fracture of war (Demon Lover 192). Bowen's enduring preoccupation with the existential threat of the seemingly empty Irish landscape thus haunts her description of a blitzed, bewildered city and its supernaturally charged nonhuman life.

\section{"A Country of Ruins": The Irish Gothic Landscape}

Many of the stories in The Demon Lover endow plants, flowers, and trees with an uncanny agency. In "Green Holly" the holly moves whenever the ghost appears, and in its companion piece, "Ivy Gripped the Steps," the ivy destroys Mrs. Nicholson's house with a vigor that feels calculated. "Ivy gripped and sucked at the flight of steps," the story famously begins, "there was something brutal about its fecundity. It was hard to credit that such a harvest could have been nourished only on brick and stone [. $\quad]$ [O]ne could have convinced oneself that the ivy must be feeding on something inside the house" (114). Nature now feeds on humanity rather than the reverse-feeding with a luxuriance that is indeed "frightening." Such an ivy-smothered ruin, an archetypal image of the gothic, is also a defining image of the Irish landscape. Thus I turn to Bowen's Irish writing to contextualize the terse, malevolent energy of the natural world depicted in The Demon Lover.

In her family history Bowen's Court (1942), written during the same period as the wartime stories, Bowen observes:

It will have been seen that this is a country of ruins. Lordly or humble, military or domestic, standing up with furious gauntness, like Kilcolman, or shelving weakly into the soil, ruins feature the landscape - uplands or river valleys - and make a ghostly extra quarter to towns. They give clearings in woods, reaches of mountain or sudden turns of road a meandering and pre-inhabited air. Ivy grapples them; trees grow inside their doors; enduring ruins, where they emerge from ivy, are the limestone white-grey and look like rocks. [. ] Campaigns and "troubles," taking their tolls, subsiding, each leave 
a new generation of ruins to be absorbed slowly into the natural scene. $(15-16)$

This "natural scene" or ruin-haunted landscape slowly absorbing the signs and structures of human existence is home ground for Bowenindelibly linked to an Anglo-Irish history freighted with violence and conflict. The "troubles" of colonial history leave ruins, certainly, and in her Irish writing landscape often functions as a means of articulating colonialism's violent and dislocating effects, frequently by depicting the symbiotic relation of the land to the "native" Catholic tenants. ${ }^{4}$ Although I acknowledge the just force of such readings made in studies of Bowen and Irish writing more generally, I also argue for Bowen's apprehension of a more primal menace in the natural world, one less obviously attached to its human inhabitants. Bowen's Court opens with an exhaustive description of the countryside surrounding the author's ancestral family home, an intricate depiction offering an aerial view of a willfully and wilily deceptive landscape:

The country is not as empty as it appears. Roads and boreens between high hedges, sunk rivers, farms deep in squares of sheltering trees all combine by their disappearance to trick the eye [. ] $[T]$ he country conceals its pattern of life, which can only wholly be seen from an aeroplane. This is really country to fly over-its apparent empty smoothness is full of dips and creases [. ] No, it is not lack of people that makes the country seem empty. It is an inherent emptiness of its own. (4-5)

This increasingly fretful meditation on the signification of empty can be read as the quintessential perspective of the colonizer, but it is the ontology of the landscape itself, rather than its occupants, that agitates the authorial eye. This vexed engagement with the Irish landscape again becomes apparent when Bowen offers the perplexed view

4. For example, this passage in The Last September describing the countryside around the big house of Danielstown: "Behind the trees, pressing in from the open and empty country like an invasion, the orange bright sky crept and smouldered" (22). In Bowen's later big-house novel AWorld of Love (1955), the Englishwoman Lilia lives "with the sense she'd had since she came to Montefort of being besieged, under observation, or in some way even under a threat. [. ] Was it the place itself, her mistrust of Ireland, or the uncanny attentiveness of the country which kept her nerves ever upon the stretch?' (AWorld of Love, 53). 
of another anxious colonizer, Edmund Spenser, who had himself memorably gothicized the Irish landscape in the sixteenth century.

He liked little in Ireland: his position was sinister and desolating - he was a civil servant, living on granted land. His castle, Kilcolman, lies two miles north-west of Doneraile, on an exposed plateau under the Ballyhouras; the marsh where gulls breed was once his smiling lakebut he never cared for its smile. Kilcolman keep, a torn-open ruin, still stands; winds race round it at every time of the year. The view is of Ireland at its most intimidating - the marsh, the heartless mountains with their occasional black frown. That landscape fulfilled, for Spenser, its conveyed threat: the castle was burnt by the Irish in his absence, and one of his sons, an infant, died in the fire. (Bowen's Court 7)

Although Bowen includes a verbal nod to his seminal text, $A$ View of the Present State of Ireland (1596), Spenser is of interest here through his geographical and colonial presence in Ireland. Noticeably, she singles out the landscape itself as the source of "threat" and obliteration for Spenser; the Irish who burned his castle are mentioned almost as an afterthought.

The effacement of human figures in this elemental conflict is distinct, reflecting a studied Anglo-Irish determination "not to notice" as things fall apart-a colonialist outlook that conveniently expunges the human element of the territory it seeks to possess. But the passage also suggests a more unconventional ecological perspective of a nature that nurtures a calculating aggression beneath apparent "emptiness" - a pointedly anthropocentric view. Bowen's background bequeathed to her a heightened sensitivity to the ownership of territory: who, if anyone, has a right to own land? Can landscape itself have consciousness and agency? What legal rights might nature have, particularly in a period of unprecedented anthropogenic environmental destruction? ${ }^{5}$ Such inquiry is not surprising

5. The legal concept of "environmental personhood" first gained real traction in the 1970s with the work of Professor Christopher Stone: "Should Trees Have Standing? Toward Legal Rights for Natural Objects," Southern California Law Review 45 (1972): 450. On 20 March 2017 the New Zealand Parliament passed the Te Awa Tupua (Whanganui River Claims Settlement) Act, declaring this river as a legal entity with "all the rights, powers, duties, and liabilities of a legal person." See Te Awa Tupua (Whanganui River Claims Settlement) Act (2017), New Zealand Legislation, 
from a writer widely noted for endowing consciousness where one least expects it. Maud Ellmann, for example, argues that "Bowen's addiction to the tropes of personification and prosopopoeia creates the sense that every object has a psyche; in fact, her objects even have neuroses - every house, for instance, has a watchful face; every car a gamut of anxieties" (147). Might the natural world resent its ruthless colonization and casual destruction by humans - and if so, what forms will a terrestrial resistance assume? An ivy-strangled ruin might be an image that comes to mind, offering a view of nature that profoundly challenges our human-centered relationship with the natural world, including our aesthetic response to it. The sublimity of natural landscapes - see the album of Swiss views of "fuming cataracts and null eternal snows" (679) that Arthur looks through in "The Happy Autumn Fields" - can overwhelm and leave us in astonishment, or what Edmund Burke describes as the "state of the soul in which all its motions are suspended, with some degree of horror" (53). Yet Bowen exceeds this Burkean sublime by endowing landscape with its own utterly nonhuman consciousness and agenda. Stemming from her Irish background, Bowen's interest in hostile, empty terrains and landscape moves beyond the sublimity of romantic ruin into the realm of apocalyptic extinction. Such heightened ominousness shapes the The Demon Lover's cumulative depictions of a natural world at best ambivalent, at worst, inimitably hostile, to its occupiers.

\section{Strange Growths inWar Climate: The Natural World in The Demon Lover}

The natural world, especially its flowers, was a crucial thematic reservoir for Bowen throughout her career, but it became markedly focalized by the crisis of World War II. In a postscript to The Demon Lover

Parliamentary Counsel Office, http://www.legislation.govt.nz/act/public/2017/0007 /latest/whole.html. In the same year the Colorado River ecosystem brought a lawsuit against the state of Colorado for violating its constitutional rights; see Matthew Miller, "Environmental Personhood and Standing for Nature: Examining the Colorado River Case," University of New Hampshire Law Review 17 (2019). More generally, the rights of nature in relation to the concept of human rights form an increasingly dynamic field of jurisprudence. 
Bowen writes that these stories are "all war-time, none of them war, stories [. ] These are, more, studies of climate, war-climate, and of the strange growths it raised. I see war (or should I say feel war?) more as a territory than as a page of history" (191). If this "territory" of war is lawless and outside human control, that word also connotes colony, power, and jurisdiction. And this territory facilitates "strange growths," which, on the evidence of the stories themselves, one may take quite literally. Always a precise, if often obfuscating writer, Bowen's use of "strange" registers an appropriately gothic note, a nonhuman agency deeply fraught with unsettling potential. In The Demon Lover human civilization is under threat of annihilation not only from its own internecine conflict but also from the "rising tide" of an aggressive natural world that capitalizes on the chaotic ruptures of global war (192). This theme builds in the collection by accretion, much like the growth of ivy on an abandoned building. Nature, quietly introduced as a key presence in the opening page of the first story, "In the Square," thereafter develops in slow, steady vines that compass crucial scenes and themes. "Sunday Afternoon" is set in a chilly spring garden - the only story in the collection located unambiguously in Ireland. The ilex woods in "The Inherited Clock" are the "sombre playgrounds" for the "inescapable games with Paul" that have left the adult Clara traumatized (35). In "Songs My Father Sang Me" a returned soldier abandons his daughter in a remote rural idyll. The volume's titular story "The Demon Lover" begins on the ominous note that "no human eye watched Mrs. Drover's return to her house," and a pivotal narrative scene takes place in a dark, oppressive garden (80). The theme of nature's aggressive encroachment accelerates dramatically in the final five stories: "The Happy Autumn Fields," "Ivy Gripped the Steps," "Pink May," "Green Holly," and "Mysterious Kôr."

Taking my cue from the author to tease a reading out of this tangled and entangling theme, I read The Demon Lover not as a disparate assembly of occasional stories but as an organic whole. Although the stories may not consciously have been written with the intention of forming a single volume, once Bowen read the proofs, she was

most struck by what they have in common. This integrates them and gives them a cumulative and collective meaning that no one, taken singly, has by itself. The Demon Lover is an organic whole: not 
merely a collection, but somehow-for better or worse-a book. Also the order in which the stories stand-an order come at, I may say, casually — seems itself to have a meaning or to add a meaning I did not foresee. (192)

The stories repay rereading within and across the context of the "organic whole"; like layers of soil, meanings thicken from one story to the next. "In the Square," the opening piece, is set in a London garden square, an appropriately ambiguous location that is both urban and rural, a city-space allocated to nature cultivated for human leisure. The square is "mysterious," full to the brim with the "whitish reflection" of "the pale-coloured facades" of the houses; the "grass was parched in the middle; its shaved surface was paid for by people who had gone" (7).The anthropomorphized grass, the visual embodiment of human control of nature, offers an eerie and effective point of contrast with the chaotic destruction of war, also starkly apparent: "The sun, now too low to enter normally, was able to enter brilliantly at a point where three of the houses had been bombed away; two or three of the may [hawthorn] trees, dark with summer, caught on their tops the illicit gold" (7). The bomb has exposed the vivid colors of interior wallpapers - viridian, yellow, coral — that, like the "illicit gold" on the tops of the may trees to which they are linked by cause and effect, contrast starkly with the otherwise gothic coloration of the "extinct scene" (7). Such ruin in a thriving natural scene represents an imaginative crux for Bowen, a key recurring image throughout The Demon Lover, most obviously in "Ivy Gripped the Steps."

May trees later return as a key player in "Pink May," wherein a nervy protagonist relates her experience of a peculiar haunting, one strangely attuned to the flowering mays outside her bedroom window. In traditional folklore the hawthorn's magic is especially potent in its flowering month of May, with a sexual aspect to its cultural persona: the "stale sweet scent from the trimethylamine the flowers contain," according to the English poet and naturalist Geoffrey Grigson, "makes them suggestive of sex" (181). Adultery, a subdued subplot for "In the Square," is the primary focus of "Pink May," and both stories focus on the women involved - in the first, the female lover of a married man; in the latter, the wife who embarks on an affair. "Pink May" can be read as the story of an unconventional haunting - of a woman possessed by an eponymous tree that has impelled her affair: 
"The glare on the trees used to make me blink, and the thick sort of throaty smell of the may came in. I was never certain if I liked it or not, but it somehow made me feel like after a drink" (153). ${ }^{6}$ The narrator is also persecuted by a more conventional ghost, an aggressively puritanical female presence strangely linked to the may trees that freeze into preternatural stillness when she appears. This double haunting comprises a thematic coil of the feminine, sexuality, and a gothicized natural world that recurs frequently in The Demon Lover. In the Christmas ghost story "The Cheery Soul," the ghost is a murdered female cook who twists mistletoe, an ancient symbol of fertility, "around the cord of the hanging electric light" (61). ${ }^{7}$

Often this cluster of femininity, sexuality, and gothic nature upends or critiques the tired gender conventions of the gothic. ${ }^{8}$ For example, the pattern of a sexually aggressive female pursuing a disinterested man recurs in several of the stories. Sexuality, of a signally frustrated kind, pervades The Demon Lover, leading to an aggregated, if sublimated, concern with reproduction. In a kind of comic reversal of "Pink May," the ghost of "Green Holly" is a sexually aggressive "mopsy" (the story is set in a house named "Mopsam Grange") who amorously pursues Winterslow, a government employee who is as

6. A woman is possessed by a tree in another story of Bowen's, "The Apple Tree" (The Cat Jumps, 1934), one of her most extraordinary images of haunting entwined with natural imagery. In this story, a gothic reworking of the Greek myth of Daphne, the woman is haunted by the apple tree on which her school friend committed suicide. Such an insidious organic possession is infinitely more powerful than the common- or garden-haunted house. "I make rooms impossible," Myra states, "I am not like a house that can be burnt, you see, or pulled down" (Collected Stories 470).

7. This mordant parody of the seasonal tradition serves as a compressed and compelling paradigm of Bowen's often unsettling perspective on modernity. Bowen's gothicized natural world can be read as a significant and underappreciated constituent of her modernism, especially the means by which her writing resists traditional realist modes.

8. In her introduction to a 1947 edition of Sheridan Le Fanu's Uncle Silas, Bowen castigates the tired, "well worn" plots and stock characters of the gothic, commenting disparagingly on the "perpetual Beauty in Distress" who "ran to excess in the gothic romances but is not finished yet-the distraught young lady clasping her hands and casting her eyes skyward to Heaven: she has no other friend" (Collected Impressions 3). Her critique, both playful and savage, of such conventions in The Demon Lover is emphasized when the title of another of Le Fanu's gothic masterpieces, In A Glass Darkly (1872), is evoked only to be dismembered in the course of "Green Holly": "the scene-the hall, the stairs and the gallery-faded under this fog-dark but glass-clear veil of hallucination" (170). 
sterile and sexually passive as his name suggests. The other male protagonist, Rankstock, is similarly named for barrenness, and is repeatedly emasculated in the course of the narrative. In "Ivy Gripped the Steps" the lingering presence of sexual predator Mrs. Nicholson haunts the emasculated and estranged Gavin Doddington. Bowen uses ivy's longstanding association with the feminine in this story to complement the pronounced emasculation of the robust and prickly holly in "Green Holly," traditionally coded as quintessentially male: Winterslow stamps "derisively" on a holly leaf, while Rankstock sits on it (170). Virility and reproduction, the fundamental drive of the natural world, is the concern: the ivy's vampiric voracity is visually emphasized in its abundant "fleshy pale green berries," the sign of successful pollination, and a marked contrast to the repeated complaint in "Green Holly" that holly is scarce and lacking in berries (114, 161, 172). In Bowen's reformulation of the age-old sexual contest of the holly and the ivy, both sides lose. ${ }^{9}$ Whereas sex and reproduction, inheritance and succession are the primum mobile of gothic narrative and of the big-house genre that Bowen knew so well, throughout The Demon Lover characters repeatedly fail to have sex. Through a gothicized natural world the stories convey muted anxieties of human extinction achieved not by global war, but by a pandemic failure to reproduce.

As demonstrated above, The Demon Lover draws heavily on the rich cultural and mythic life of the natural world. Bowen's repeated use of the may tree in particular calls attention to its symbolic presence in the collection. The may, or hawthorn, according to Grigson, is regarded "above most plants of the far west of Europe [as] a supernatural tree," and in English folk culture its power was generally viewed as apotropaic (167). In Irish folklore, however, it is known as the fairies' tree, a gateway to the otherworld of the aos sí that should not be disturbed. ${ }^{10}$ The bomb-created "breach" or "dazzling

9. In "Green Holly" Bates confuses this tune, sung by the character Amiens in Shakespeare's As You Like It, with "a Christmas carol" (165), evoking not only the well-known carol "The Holly and the Ivy" but also an older English carol, "The Contest of the Ivy and the Holly," that relates a battle of the sexes that masculine holly wins: "Nay, Ivy, nay it shall not be, I wis / Let Holly have the mastery, as the manner is" (Husk 31). Grigson records a medieval poem on the same subject: "Holly and his merry men / Sitt in chaires of gold; / Ivy and her jentell women / Witt without in fold" (Grigson 
breach" (the word is repeated within the space of a page) that allows the sun- light to kindle the may trees in "In the Square" might be read as a break between our world and another, facilitating a flux of supernatu- ral energy entwined with nature into the metropolis (7). It is symbolic too of a more widespread breaking down of barriers, psychological as well as physical, and affecting all life in wartime London. The some- what unwilling hostess Magdela observes of her house, "Now the place seems to belong to everyone. One has nothing except one's feelings." Rupert responds by commenting on the sunlit may trees: "How curious that light is,' he said, looking across at the gap" (16). In wartime, even in bombed-out Britain, "much has been germi- nating," remarks Bowen in her postscript to The Demon Lover (196). The breaching of other boundaries throughout the stories amplifies a rupture in social relations: between the mundane and the supernatural, the masculine and the feminine, the human and the nonhuman. These psychological and physical fractures of war are exploited by an inva- sively proliferating natural world that lays claim to the ruined houses of "In the Square" as determinedly as any of its human occupants.

\section{Empty and Posthuman Landscapes: "The Happy Autumn Fields" and "Ivy Gripped the Steps"}

The hostile, aggressive maneuvers of nature provide the structur- ing energies to two of the collection's most acclaimed stories: "The Happy Autumn Fields" and "Ivy Gripped the Steps," with the Irish context more apparent in the former. ${ }^{11}$ "The Happy Autumn Fields"

10. See, for example, William Allingham's sinister and much anthologized poem "The Fairies" (Poems, 1850), which warns against digging up thorn trees planted by fairies: "Is any man so daring / To dig up one in spite, / He shall find the thornies set / In his bed at night" (89). W. B.Yeats included his poem "The Wicked Hawthorn Tree," a gothic lyric on a ghostly big house, as part of his 22 April 1937 BBC broadcast "In the Poet's Parlour." The poem crystallizes some of the key anxieties explored here as a "wicked, crooked hawthorn tree" relates the extinction of the Ascendancy aristocracy, now "cold blown dust or a bit of bone." "The Wicked Hawthorn Tree" was first published in Broadsides: A Collection of Old and New Songs, 1935 (Dublin: Cuala Press, 1935).

11. Although Bowen's wartime fiction is often studied as Irish gothic writing or within the immediate historical context of World War II, the work of Thomas S. Davis has also shown that in fact the two are closely connected. Davis argues that Bowen's 
oscillates between a late-Victorian Anglo-Irish estate and a bombedout 1940s London terrace, with its parallel narratives characterized by dislocation and environmental rupture. ${ }^{12}$ The story begins with an Anglo-Irish family walking its estate and confidently asserting the landscape's environmental harmony with their possession of the property: "The field and all these outlying fields knew as Sarah knew that they were Papa's" (94). The direct, uncomplicated flow of this sentence from a writer renowned for her clause-heavy, clotted-andknotted syntactical style is worth noting. However, signs of ecological strain already appear when the sons take "imaginary aim" at the rooks (94) in a casually ominous reference to the nearby cottage of a dying tenant, soon to become another ruin: "one day we shall pass and see no more smoke; then soon his roof will fall in" (97). The neighboring squire Eugene, bending down before one sister, brushes back a lock of hair, a "sublime act" that intimates his impending doom (100). ${ }^{13} \mathrm{~A}$ sense of foreboding thickens in the closely observed gathering of the family after dinner in the drawing-room:

Now the sun was setting behind the trees, but its rays passed dazzling between the branches into the beautiful warm red room. The tips of the ferns in the jardinière curled gold, and Sarah, standing by the jardinière, pinched at a leaf of scented geranium. The carpet had a great centre wreath of pomegranates, on which no tables or chairs stood, and its whole circle was between herself and the others. (104) $)^{14}$

gothic stories "treat the war populism of the 1940s and the calls for a more equitable postwar democracy as augurs of the same economic and social disaster that befell the Anglo-Irish landowners." Thus, for Bowen, "a genre initially suited for a dying settler colonial class is uniquely, if counter-intuitively, appropriate for a bombed imperial metropolis" (Davis 29). In Bowen criticism generally, Patricia Coughlan identifies an emerging consensus that "Ireland with its disruptive narratives is an always ghosting presence throughout the work, significant not merely in specifically Irish scenes" (Coughlan 210).

12. Though it is never explicitly stated that the flashback sections of this story are set in Ireland, most readers "instinctively feel," as Neil Corcoran puts it, that this is the case (148).

13. This intense moment of an emotional sublime and a doomed lover framed in a hostile landscape also features in The Last September as Lois and Gerald's relationship fizzles out: "In her impotence, her desolation-among the severe trees-at not being compelled, she made a beseeching movement which he, remote in a rather sublime perplexity that transcended pain, either ignored or rejected" (190).

14. Geraniums feature in “The Back Drawing-Room” (Ann Lee's \& Other Stories, 1926), another temporally fractured gothic Irish story, in which a traveler lost in Ire- 
Reverberations of the collection's opening story unsettle the apparent harmony of the Anglo-Irish in their paradisal world. The setting sun that goldens the tips of the ferns echoes the sunset-kindled may trees and breach-exposed wallpapers of "In the Square"; Eugene is "transfigured by the strange light [. ] The wallpaper now flamed scarlet behind his shoulder" (106). The wreath of pomegranates suggests the Persephone myth, closely associated with fertility and renewal, although it is Eugene who, carefully enfolding in his handkerchief a shred of the geranium leaf that Sarah has in her distress shredded, is bound for the underworld. ${ }^{15}$ Later that evening he is "thrown from his horse and killed [. [T] ]he evening, which was in autumn, was fine though late. [Sarah's brother] Fitzgeorge wonders, and says he will always wonder, what made the horse shy in those empty fields" (113). ${ }^{16}$ Henrietta's possessiveness of her older sister seems to precipitate the lover's demise- "Whatever tries to come between me and Sarah becomes nothing," she tells him, in another example of the collection's clustering of a supernaturalized natural world, sexuality, and the feminine; yet the landscape itself, the empty fields, finally executes Eugene. The decline of the Anglo-Irish as a class is implied in the brutal curtailing of Sarah and Eugene's delicately burgeoning relationship - another of the collection's many examples of human failure to reproduce. Mary, we learn, does not

land wanders into a big house to discover a woman weeping in a room "that smelt chiefly of geraniums" (Collected Stories 207). The traveler subsequently discovers that this house had been burned to the ground several years previously, and the family (who have moved away) are spoken of as "though they were dead. 'Well, how can one feel they're alive? How can they be, any more than plants one's pulled up? They've nothing to grow in, or hold on to'" (210). Bowen's language here reiterates the breaking down of barriers between human and plant life.

15. Emmanual Vernadakis reads one of Bowen's earliest stories, "Daffodils" (Encounters, 1923) as a remaking of Eleusinian myth (see Vernadakis 2000). The story closely engages with aesthetic attitudes to nature in the figure of the daffodil, perhaps the ultimate symbol of Romantic imaginative exuberance in the natural world.

16. A fallen petal foreshadows the death of a lover in The Last September, as Lois reads a letter from Gerald: "Noiselessly, a sweet-pea moulted its petals on to the writing-table, leaving a bare pistil. The pink butterfly flowers, transparently balancing, were shadowed faintly with blue as by an intuition of death" (163). Later, on her way to prune the sweet-peas, she encounters Hugo "walking by himself up the shrubbery path. Pulling leaves from the laurels he shredded them carefully" (164); given the association established between laurels and Laura, such a scene reads as a similar organic imaging of a lover's death. 
descend lineally from Sarah as the sisters "likely both died young" and presumably childless (113). Eugene's lonely death in the empty fields is a symbol befitting the violent end to the bewitching concord of house and land, the big house and its demesne, as famously imagined by W. B.Yeats in "Ancestral Houses" (The Tower, 1928):

Surely among a rich man's flowering lawns

Amid the rustle of his planted hills

Life overflows without ambitious pains

And rains down life until the basin spills. (200)

The following story in The Demon Lover, "Ivy Gripped the Steps," posits a pervasive sense of a hostile natural world gradually eroding casual assumptions of human superiority or ecological dominance. Southstone and its wealthy inhabitants, we are told, have escaped "the brutishness that comes from any dependence upon land," the adjective ironically invoking the "brutal" ivy of the story's opening passage (122). As a "fairy-tale" of urban consumer modernity and a "town without function," Southstone's "magical artificiality" appears to be emblematized by its subjugation of the natural world $(121,125)$. The town embraces its climate of wealth and privilege that "change from season to season, the roughest Channel gale blowing, could not disturb" (121). The very calendar of the natural world has been remade to accommodate the lavish tastes of a leisured, moneyed elite: Gavin is astonished by "the earliness of the purple and white sweet pea-at the Doddingtons', sweet pea did not flower before July" (119). In Southstone, in "early January [. . .] [d]elayed late autumn and forced early spring flowers blazed, under artificial light, against the milder daylight outside the florist's plate glass" (132).

The onset of war, however, brings "desuetude and decay" to Southstone as nature moves to reclaim its territory, most strikingly in the homes of Mrs. Nicholson and Admiral Concannon (115). At the close of the story Gavin spies on an ATS girl as she arranges blackout drapes in what had once been the home of the Concannons. These last slivers of electric light are linked physically and metaphorically to flowers growing in cracks in the pavement outside: "Light staggered, a moment longer, on the desiccated pods of the wall-flowers that, seeded from the front garden, had sprung up between the cracks of the pavement [. ] At last she had stopped the last crack of light" 
(148-49). The Concannons' house will soon suffer the same "gothic fate" as the home of Mrs. Nicholson (115); the narrative thereby invokes by extension a more sweeping image of a posthuman landscape, as nature continues its slow, steady assimilation of Southstone. The above reading departs from the usual critical decoding of the story's ivy as metaphorically representing Mrs. Nicholson's suffocating personality. I rely instead on the ivy as ivy, part of a wild nature beyond human control and, moreover, actively asserting its autonomy: "the process of strangulation could be felt: one wondered how many more years of war would be necessary for this to complete itself" (114). This interpretation reflects recent developments in environmental criticism that attend to the agency of nonhuman culture in modernist literature and insist, in the words of Jeffrey Mathes McCarthy, "that humans recognize themselves as entities among entities, beings among other beings with their own ends" (5). Such nonhuman agency poses profound challenges for our understanding of how we exist in a world neither centered on nor dominated by humans. This anxiety-how to make durable the physical signs and structures of existence-must have represented a particular pressure on a writer for whom the solidity of houses was a psychological necessity. Bowen recalled that even as a child she "found something reassuring and comforting in the idea that, whatever happened, buildings survived people" (Afterthought 111). In a 1951 broadcast she asked: "Our emotions, even our senses, seek something stable to cling to. How can we not seek, in some form, an abiding city?" (Listening In 98).

In "Mysterious Kôr," The Demon Lover's concluding story, Bowen imagines a city impervious to the ceaseless onslaught of nature. Pepita and Arthur are another couple who fail to have sex, frustrated in the first instance by the bright moonlight illuminating Regent's Park, as Corcoran elucidates, an "impossibly public space, even at midnight, and then by the prudish or innocent friend Callie, who has resisted all hints that she might leave the flat to the lovers alone" (Corcoran 156). As the would-be lovers wander the "shallow, cratered, extinct" capital, Pepita shares with Arthur her imagining of mysterious Kôr, "a completely forsaken city, as high as cliffs and as white as bones, with no history" $(173,175)$. When Arthur observes that a city uninhabited for thousands of years "would have fallen down," Pepita responds "with immediate authority": "Kôr's altogether different; it's 
very strong; there is not a crack in it anywhere for a weed to grow in" (175). Later, in a dream, she looks "down the wide, void, pure streets" of this perfect, abiding city, and "went up the stairs down which nothing but moon came"; here, there is no ivy to grip the steps (189). Yet the story makes clear that the separation between human and nature can be sustained only in this imagined city. That is to say, a city entirely free from nature can only be imaginary. There is a striking coincidence here with another poem from Yeats's The Tower, "Sailing to Byzantium," a poem depicting an imagined journey from a sensuous natural living world to an artificial city of art: "out of nature," utterly removed from the seasonal rhythms of "those dying generations" who "commend all summer long / Whatever is begotten, born, and dies" (193).Yeats's Byzantium, we might argue, is the ultimate urban city that has left nature entirely behind. ${ }^{17}$ Yet for Bowen such separation remains illusory. Even in Kôr a seed of nature is present, for Pepita bears within herself Kôr's inevitable and gothic ruin under the force of nature (pepita meaning a pumpkin seed). As part of the natural world, humanity can no more detach itself from nature than from the passage of time. Thus we are locked into an endless war with nature itself, a struggle for dominance that as individuals, and increasingly as a species, we will inevitably lose-in perhaps the most archetypally gothic narrative of all.

\section{Conclusion}

Bowen's interest in the natural world originates from her Irish roots and spreads rhizomatically through her work, achieving particular intensity in her wartime short fiction. Her preoccupation with the "empty" Irish countryside anxiously anticipates the erasure of the Ascendancy class from that landscape-fears revivified and amplified in the 1940s when war-induced human annihilation on a global scale became a distinct possibility. From The Demon Lover's opening page, nature thrives in the chaos and ruins of war. In exploring the agency of the nonhuman, Bowen compasses the capability of the natural world to obliterate as effectively as a doodlebug all

17. I am grateful to Dr. Michael McAteer for allowing me to read his essay, "W. B.Yeats's Oriental City," forthcoming in Lehner and Sturgeon from Cork University Press. 
signs of our existence, envisioning mass human extinction. Yet ultimately this engagement with the natural world as ontological other sidesteps geopolitical borders and long standing vexatious questions of national identities to put new emphasis on ecological relations. It insists on recognizing humanity as part of, rather than superior to, the natural world.

"A week after V. E. Day, the nightingale came to Londonunnoticed until it began to sing" (Collected Stories 751). With these words Bowen began her first postwar story "I HearYou Say So,"written immediately after the war in Europe ended in May 1945 and published in September of that year.The return of this much-storied bird to London, in keeping with its seasonal migration between Europe and sub-Saharan Africa, seems unreal to those who hear it; one character thinks it must be a recording played on the wireless. Her companion insists that the night-singing bird must be a thrush, nightingales being only "for them in the past" (753). Another remarks that the singing comes "much too soon, after a war like this. Even Victory's nearly been too much. There ought not to have been a nightingale in the same week" (755). To the shell-shocked, weary survivors of war, the beauty of the nightingale's song is too much to bear. Still, it projects a fragile and evocative symbol of hope for the renewal of a warravaged world, depicted by Bowen with romantic and lyric intensity:

Unseen rays of night pin-pointed the nightingale, in the concentrated and somehow burning blackness of its unknown tree. It sang into incredulity like the first nightingale in Eden. Note after note from its throat stripped everything else to silence: there was nothing but the absolute of its song. It sang from a planet, beyond experience, drawing out longings, sending them back again frozen, piercing, not again to be borne. (753)

The story closes with a young war-widow standing in her late husband's childhood room, listening to the nightingale "with profound happiness [. ] Disjected lines of poetry, invocations, came flooding into her mind. I cannot see what flowers are at my feet. She looked down at the carpet, wondering if a secret were in its pattern. Naturally, it was too dark to see" (757; emphasis in original). After the violent fractures of war (the striking word disject means to dismember by force), the nightingale's song appears to promise a restoration of 
harmonious relations between the human and the natural world. The scene evokes the tantalizing possibility of living with and within a romantic Keatsian nature, where the sublimities of the natural world might overwhelm but not annihilate. But such a possibility remains qualified: it is too dark for the young widow to see the pattern of the carpet where the secret of harmony between man and nature may or may not be hiding.

\section{Works Cited}

Bowen, Elizabeth. Afterthought: Pieces about Writing. London: Longmans, Green, and Co., 1962.

- Bowen's Court \& Seven Winters. London: Vintage, 1999.

. Collected Impressions. London: Longmans Green, 1950.

- The Collected Stories of Elizabeth Bowen. London: Jonathan Cape, 1980.

—. The Demon Lover. London: Jonathan Cape, 1947.

- The Last September. London: Penguin Modern Classics, 1990.

- Listening In: Broadcasts, Speeches, and Interviews by Elizabeth Bowen. Ed. Allan Hepburn. Edinburgh: Edinburgh University Press, 2010.

—. The Little Girls. London: Penguin Modern Classics, 1982.

- People, Places, Things: Essays by Elizabeth Bowen. Ed. Allan Hepburn. Edinburgh: Edinburgh University Press, 2008.

- AWorld of Love. London: Penguin Modern Classics, 1983.

Burke, Edmund. A Philosophical Enquiry into the Origin of Our Ideas of the Sublime and the Beautiful. Ed. Adam Phillips. Oxford: Oxford World's Classics, 2008.

Corcoran, Neil. Elizabeth Bowen: The Enforced Return. Oxford: Clarendon Press, 2004.

Coughlan, Patricia. "Elizabeth Bowen." A History of Modern Irish Women's Literature. Ed. Heather Ingman and Clíona Ó Gallchoir. Cambridge: Cambridge University Press, 2018.

Davis, Thomas S. "Elizabeth Bowen's War Gothic." Textual Practice 27.1 (2013): 29-47.

D'hoker, Elle. "The Poetics of House and Home in the Short Stories of Elizabeth Bowen." Orbis Litterarum 67.4 (2012): 267-89. 
Ellmann, Maud. "Shadowing Elizabeth Bowen." New England Review 24.1 (Winter 2003), 144-69.

Glendinning, Victoria. Elizabeth Bowen: Portrait of a Writer. London: Weidenfeld and Nicholson, 1977.

Grigson, Geoffrey. The Englishman's Flora. London: Phoenix, 1955. Grusin, Richard, ed. After Extinction. Minneapolis: University of Minnesota Press, 2018.

Husk, W. H. Songs of the Nativity. Cambridge: Cambridge University Press, 2014.

Im, Jeannie. "Elizabeth Bowen's Negative Epics: Landscape and Realism in The Last September and A World of Love." TwentiethCentury Literature 61.4 (2015): 460-83.

Lassner, Phyllis. Elizabeth Bowen: A Study of the Short Fiction. New York: Twayne, 1991.

Lehner, Stefanie, and Sinéad Sturgeon, eds. Reimagining Irish Urban Cultures. Cork: Cork University Press. Forthcoming.

Lively, Penelope. Life in the Garden. London: Fig Tree, 2017. Lytovka, Olena. The Uncanny House in Elizabeth Bowen's Fiction.

Frankfurt: Peter Lang, 2016.

McAteer, Michael. "W. B. Yeats's Oriental City." Reimagining Irish Urban Cultures. Ed. Stefanie Lehner and Sinéad Sturgeon. Forthcoming, Cork University Press.

McCarthy, Jeffrey Mathes. Green Modernism: Nature and the English Novel, 1900-1930. Basingstoke: Palgrave Macmillan, 2015.

Smith, Andrew, and William Hughes, eds. Ecogothic. Manchester: Manchester University Press, 2013.

Vernadakis, Emmanuel. "Christening Pagans: Onomastics and Plot in Elizabeth Bowen's 'Daffodils,' 'Her Table Spread,' and 'Look at All Those Roses." Journal of the Short Story in English 34 (2000): 119-37.

Wasson, S. Urban Gothic of the Second World War: Dark London. London: Palgrave Macmillan, 2010.

Wurtz, J.F."Elizabeth Bowen, Modernism, and the Spectre of AngloIreland." Estudios irlandeses 5 (2010): 119-28.

Yeats, W. B. The Poems. Ed. Richard J. Finneran. London: Macmillan, 1984. 